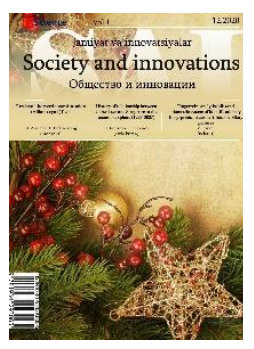

\title{
Modern models of social partnership in Uzbekistan
}

\section{Alisher MUMINOV ${ }^{1}$}

National University of Uzbekistan

\begin{tabular}{l} 
ARTICLE INFO \\
\hline Article history: \\
Received September 2020 \\
Received in revised form \\
15 October 2020 \\
Accepted 15 November \\
2020 \\
Available online \\
31 December 2020 \\
\hline Keywords: \\
Citizens \\
Society \\
NGOs \\
Entrepreneurship \\
Farming, partnership \\
Perspective \\
Unification.
\end{tabular}

\section{Ўзбекистонда моделлари}

\begin{abstract}
Currently, the special importance of social partnership is acknowledged as an effective mechanism for involving the general public in participation in the socio-political, socioeconomic and cultural life of the country in Uzbekistan.

In this regard, the President of the Republic of Uzbekistan Sh.Mirziyoyev pointed out the need for consistent implementation: "the principle of mutual responsibility of citizens, the state and society, the connection of their rights and obligations.

This principle serves as the basis for effective interaction between the state and the individual, the state and civil society in solving the important tasks facing our country.

This article is devoted to the analysis of reforms aimed at the development of social partnership in Uzbekistan.
\end{abstract}

2181-1415/C) 2020 in Science LLC.

This is an open access article under the Attribution 4.0 International (CC BY 4.0) license (https://creativecommons.org/licenses/by/4.0/deed.ru)

Калит сўзлар:
Фуқаролар
Жамият
Нодавлат ташкилотлар
Тадбиркорлик
Фермерлик
Шерикчилик
Истиқбол
Бирлашиш.

\begin{abstract}
АННОТАЦИЯ
Хозирда ўзбекистон ижтимоий шерикликнинг алохида ахамиятини жамоатчиликни мамлакатнинг ижтимоийсиёсий, ижтимоий-иқтисодий ва маданий хаётига жалб қилишнинг самарали механизми сифатида тан олмоқда.

Шу муносабат билан ўзбекистон республикаси президенти ш.мирзиёйев қуйидагиларни изчил амалга ошириш зарурлигини таъкидлади: «фуқароларнинг, давлат
\end{abstract}

\footnotetext{
${ }^{1}$ Doctor of political science, Professor, National University of Uzbekistan, Tashkent, Uzbekistan E-mail: sala-0044@mail.ru
} 
ва жамиятнинг ўзаро жавобгарлиги принципи, уларнинг хукуқ ва мажбуриятлари ўзаро боғлиқлиги.

Ушбу тамойил мамлакатимиз олдида турган мухим вазифаларни хал қилишда давлат ва шахс, давлат ва фуқаролик жамияти ўртасидаги самарали ўзаро алоқалар учун асос бўлиб хизмат қилади.

Ушбу мақола ўзбекистонда ижтимоий шерикликни ривожлантиришга қаратилган ислохотларни тахлил қилишга бағишланган.

\section{Современные модели социального партнерства в Узбекистане}

\author{
Ключевые слова: \\ Граждане \\ Общество \\ HHO \\ Предпринимательство \\ Фермерство \\ Партнерство \\ Перспектива \\ Унификация.
}

\begin{abstract}
АННОТАЦИЯ
В настоящее время в Узбекистане признается особая важность социального партнерства как действенного механизма вовлечения общественности в общественнополитическую, социально-экономическую и культурную жизнь страны.

В этой связи Президент Республики Узбекистан Ш.Мирзиёев указал на необходимость последовательной реализации: "принципа взаимной ответственности граждан, государства и общества, взаимосвязи их прав и обязанностей".

Этот принцип служит основой эффективного взаимодействия государства и личности, государства и гражданского общества в решении важных задач, стоящих перед нашей страной.

Эта статья посвящена анализу реформ, направленных на развитие социального партнёрства в Узбекистане.
\end{abstract}

\section{INTRODUCTION}

All of us - citizens, society and the state -equally responsible for the prosperity of the Motherland, the strengthening of peace and stability in the country."[1]

It should be noted that a legislative framework that meets generally recognized international standards has been formed in Uzbekistan, which creates the necessary conditions for effective interaction of NGOs with state bodies in addressing actual issues of social development. In particular, in 2014 the Law "On Social Partnership" was adopted [2], in which:

- the mechanisms of interaction between government bodies and civil institutions in the development and implementation of programs for the country's socio-economic development have been fixed;

- such important areas of partnership as social protection, support and increasing social activity of the population, employment, development of small business and private entrepreneurship, farming, environmental protection, public health, the formation of a harmoniously developed and healthy young generation, increasing legal knowledge, legal awareness and legal culture of the population, strengthening the ideas of interethnic, 
intercultural and civil harmony, the revival and preservation of centuries-old, traditional spiritual, moral and historical and cultural values and others have been identified.

\section{RESULTS AND ITS DISCUSSION}

At the same time, at present, there is a tendency in the world to develop relations between the state and business in order to solve socially significant economic problems. [3]

In order to accelerate the solution of socially significant problems on mutually beneficial terms, to involve the resources of the private sector in these processes, as well as to use private entrepreneurial initiative, the Law of the Republic of Uzbekistan "On public-private partnership" came into force in June 2019 in Uzbekistan.[4] The law also provides for the introduction of effective mechanisms for dialogue with the people, the development of modern forms of public control, an increase in the effectiveness of social partnership, the development of civil society institutions, an increase in their social and political activity.

Thanks to the formed legal framework and the created conditions, in the implementation of the strong social policy pursued in the republic, along with state institutions, on the basis of social partnership mechanisms, such NGOs as "The State Fund for the Support of Entrepreneurship"("Tadbirkorlik faoliyatini qo'llab-quvvatlash davlat jamg'armasi"),[5] "National Cultural Centers"("Milliy Madaniy Markazlar"),[6] , "Fund for the Support of Free Media" ("Mustaqil ommaviy axborot vositalarini qo'llab-quvvatlash fondi") [7], "Chamber of Advocates"("Advokatlar palatasi"), [8] "Fund for supporting gifted youths"("El-yurt umidi") [9], "Union of writers"("Yozuvchilar uyushmasi") [10] and many others.

"The Yuksalish" Nationwide Movement, created in 2019, can be regarded as an NGO of a fundamentally new type, the main goal of which is to assist in the implementation of the planned reforms by:

- establishing an open dialogue with the people and the business community;

- formation of an effective system of public control;

- mobilization of efforts and forces of state authorities and administration, NGOs and other institutions of civil society, as well as citizens, especially youths;

- active participation in discussions on the implementation of the planned reforms in the chambers of the Oliy Majlis of the Republic of Uzbekistan and local councils of people's deputies;

- regular submission of analytical information and proposals to the chambers of the Oliy Majlis of the Republic of Uzbekistan, the Administration of the President of the Republic of Uzbekistan and the Cabinet of Ministers of the Republic of Uzbekistan. [11]

It is noteworthy that the presentation of "The Yuksalish" movement took place at the Forum of Civil Initiatives "National Priorities and Perspectives for Involving Civil Society Institutions in State and Public Administration" [12], where one of the main topics of discussion was the issues of social partnership as an engine of civil society.

In recent years, Public Councils [13] with the direct participation of representatives of civil society institutions have been established at all state bodies in the center and at the local level. They are entrusted with the responsible tasks of exercising public control and 
improving social partnership, including, inter alia, consideration and selection of applications received from civil institutions for a social order.

Great openness of state bodies to cooperation with NGOs has been achieved through the conclusion of contracts, development and implementation of joint projects and plans. Only within the framework of the National Forum of NGOs, annually held by the National Association of Non-Governmental and Non-Commercial Organizations of Uzbekistan (NANNOUz) [14], over 600 memorandums and agreements on cooperation have been signed between NGOs and government bodies.

One of the positive dynamics in the socio-political life of Uzbekistan in recent years is the growing involvement of the population in the process of discussing various program documents, draft resolutions, laws and other regulatory legal acts. For example, the Strategy of Actions for the Further Development of the Republic of Uzbekistan for 20172021, which includes 5 priority areas of development in the designated period, was adopted taking into account the wishes and comments from the general public of the country.

So, for example, by the Decree of the President of the Republic of Uzbekistan dated August 8, 2017 № PD-3182 [15] (article 9, part 2, paragraph 2), among the main directions of the new Concept for summing up the results of the socio-economic development of the country, it is determined: "increasing the openness and objectivity of monitoring implementation of programs of socio-economic development of regions by involving state and economic management bodies, representatives of civil society institutions, business circles and the media in its implementation."

Moreover, in order to expand the participation of citizens in managing the affairs of society and the state, to ensure the transparency of the activities of state bodies, as well as the viability and effectiveness of the adopted laws, at the beginning of 2018, the "Mening fikrim" ("My opinion") web portal [16] was created, with the help of which citizens of Uzbekistan were able" to send proposals in the form of an electronic collective appeal on actual issues related to the life of society and the state. If the appeal receives at least 10,000 votes (if it is addressed to the country's parliament), it goes to the chambers of the Oliy Majlis of the Republic of Uzbekistan for further consideration and discussion. Thus, for the first time, a single platform for public initiatives has been created in the country, which in the future may grow into a popular law-making initiative guaranteed by law and become a powerful impetus for the development of civil society as a whole.

The creation of the above listed institutional and regulatory frameworks and the necessary prerequisites allowed the Republic to move to a qualitatively new stage in the formation of a civil society in the country as a key partner of the state in the development of dialogue with the people, providing reliable guarantees for the observance of human rights and freedoms and solving problems of increasing the level of citizen involvement into public administration. The Decree of the President of the Republic of Uzbekistan "On measures to radically increase the role of civil society institutions in the process of democratic renewal of the country", adopted on May 4, 2018, was aimed at solving the relevant tasks. [17]

The Decree defines such priorities for the further development of civil society and its institutions as:

-forming mechanisms of effective and constructive dialogue between the state and civil society on the most important issues of state and social development; 
- increasing the level of participation of civil institutions in the development and implementation of social and economic development programs;

- transformation of social partnership into an effective mechanism of interaction between government bodies and non-governmental non-profit organizations on a wide range of social problems of citizens.

The implementation of the tasks of creating favorable organizational and legal conditions, as well as cooperation of state authorities with civil society institutions, contributing to the establishment of dialogue and mutual understanding between society and the state is seen in the improvement of procedural norms that determine the mechanisms for the implementation by non-governmental non-profit organizations and other civil society institutions of the legislatively provided to them rights and powers.

The positive tendency towards expanding the participation of citizens in various spheres of society's life has predetermined the need to strengthen the legislative framework. In particular, the conception of improving the rule-making activity, adopted in August 2018 [18] assumes a further increase in the level of influence of public discussions on the rule-making process by organizing effective work to involve citizens, civil society institutions, the media, business entities and representatives of the business community.

At the same time, civil institutions of Uzbekistan are involved in a completely new system of studying, considering and making decisions on appeals of individuals and legal entities from government bodies and officials. This mechanism for the protection of human rights, freedoms and legitimate interests is based on direct dialogue with the people.

The National Goals and Objectives for Sustainable Development approved by the Government for the period up to 2030 (a total of 16 national goals, 127 tasks, 206 implementation indicators) [19] envisage an increase in the participation of citizens, business entities and civil society institutions in the process of preparation and decisionmaking at all levels of government. The specified mechanism of dialogue with the people in the Republic of Uzbekistan complies with international standards and is aimed at forming an active civil society by further expanding the tools of social partnership.

As attention to the institutions of civil society and recognition of their role in energization of the participation of citizens in the life of the country, their consolidation around the urgent problems of the socio-political and socio-economic development of the country, as well as in order to support representatives of civil society institutions, the Decree of the President of the Republic of Uzbekistan established a breastplate "For contribution to the development of civil society". [20]

Moreover, additional platforms (mechanisms) continue to be created for citizens to exercise their democratic rights and freedoms for broad participation in the life of the country. In particular, in the coming period, the Presidential Decree (№. PD-4473) on all central state TV channels on a permanent basis provides for the organization of special television programs in order to discuss the most important issues of the socio-economic, political and legal life of the country (public debates). [21]

All adopted legislative acts, being aimed at increasing the activity of NGOs and other institutions of civil society, including during public discussions and public examination of draft laws, testify to the great urgency and significance of the problems of the formation and development of civil society in Uzbekistan, as well as to the efforts of the state. undertaken in this area. 
At the same time, the current legislative acts do not determine the mechanisms of the corresponding activities of NGOs and other institutions of civil society.

In this plan, it is necessary to provide for the introduction of the following parallel changes in the relevant related acts of legislation:

- unification of legal regulation of social partnership and public-private partnership, providing, inter alia, the introduction of a procedure for notification of existing social orders, similar to the procedure for notification of tenders (competitions) for the purchase of equipment and work for government agencies;

- the transition from passive into active forms of public discussion, public hearings and public expertise of draft regulations. For this purpose, it is necessary to more clearly define the procedure for the preliminary assessment of the impact of legislative acts by adopting the relevant Law;

-development of norms regulating the dialogue between the state and the people. It is advisable that the relevant legal norms stimulate people to dialogue with the state by making constructive proposals on solving certain urgent problems, and also determine the status, rights and powers in this dialogue of civil society institutions representing the interests of relevant social groups, labor collectives, neighboring communities and etc.;

- the introduction of modern forms of dialogue with the people and social diagnostics, which ensure the effective identification of problems affecting the social wellbeing of the population, and their proactive solution, as a factor in strengthening social stability and reducing political risks.

Along with this, it is necessary to take measures to stimulate the development of the infrastructure of republican NGOs at the grassroots level - directly among the population.

The study of the relevant foreign experience shows that direct work at the place of residence is one of the criteria for the development of civil society, providing the necessary conditions for the growth of civil and political participation of the population.

For example, in the historically established self-governing communities of Japan ("djichikai") [22] volunteer organizations are active, providing social support to vulnerable segments of the population. For this purpose, public funds are created, supported not only by the state, but also, first of all, by business entities. Other social formations operate within the communities, contributing to the creation of an atmosphere of good neighborhoods, mutual support and unity. Similar examples can be found in other countries around the world.

In this context, it seems appropriate to create the necessary conditions for organizing work on the territory of citizens' gatherings in all administrative-territorial units, the primary organizations of public organizations of the republican level - the "State Fund for the Support of Entrepreneurship" ("Tadbirkorlik faoliyatini qo'llab-quvvatlash davlat jamg'armasi”), Youth Support Fund, National Association of Non-Governmental Non-Commercial Organizations of Uzbekistan (NANNOUz), NGOs of women, the Federation of Consumer Rights Protection Societies, the Society of Disabled People and etc., as well as ensure their active interaction with members of the Councils of the makhalla - deputy chairmen and their advisers on relevant issues.

In addition, despite the steady increase in the role and importance of civil society institutions in the development and implementation of normative legal acts and programs of socio-economic development, there is still a low level of involvement of the population in managing the affairs of society and the state. Strengthening social partnership could be 
served by such a well-known practice of involving the general population in solving urgent social problems, such as crowdsourcing. [23]

This practice can be applied at the present stage of the development of Uzbekistan for effective interaction of NGOs with state bodies, when, with the help of crowdsourcing, namely with the participation of a wide range of participants and the use of information technologies, a search is carried out in solving actual issues of the socio-political and socioeconomic development of the country.

At the same time, it should be taken into consideration that people want to do more and are ready to think and improve the processes that surround them. They just need to be given the opportunity to participate in public discussions. Today, in the era of computer networks, crowdsourcing can unite thousands of people, involve them in a completely new system of studying, considering and making decisions on the most important issues of the country's socio-economic, political and legal life. The advantages should also include the fact that crowdsourcing often has no regional or any boundaries, it allows you to achieve results at lower costs, with little or no additional resources or effort. Most crowdsourcing projects have limited deadlines that contributors must meet. This allows not to delay the resolution of the issue, but, on the contrary, to have clear time guidelines.

Crowdsourcing is already used in Uzbekistan on the example of the discussion by the population of draft laws and program documents on the development of the country in various fields, participation in the development of the logo of the city of Tashkent and its slogan ("Tashkent loves you"), as well as in other directions.[24] It is obvious that further effective use of this mechanism in Uzbekistan will contribute to the transition to a qualitatively new stage in the formation of civil society, the development of dialogue with the people, and an increase in the level of citizens' involvement in public administration.

An interesting phenomenon of the last months of the social life of Uzbekistan, characterizing the strengthening of the status of civil society institutions as independent active actors, raising the legal consciousness of citizens in the country, has become the consolidation of society around the problem of the spread of coronavirus infection and the resulting socio-economic complications, which are felt by wide layers of the population. Social partnership in this case flows from the plane of "state-public institutions" to the plane directly social, including such institutional units as civil society institutions, entrepreneurship and the population. In order to provide assistance to the needy population, whether with medicines or food, public figures, journalists, bloggers form special channels in the "Telegram" social network, attracting the largest possible number of the residents of the country to this process. In particular, the other day it became known about the creation of the movement "Dishi, Uzbekistan" ("Breathe, Uzbekistan"), in which an initiative group of public figures and entrepreneurs of Uzbekistan came up with the initiative to purchase oxygen concentrators for patients with coronavirus undergoing treatment at home. [25]

In addition, the "Blizkiye" ("Close people") bot was launched on the "Telegram" social network, which makes it possible to help those in need locally from the side of the population living next to the needy. Since the launch of this bot, in three days out of 2874 applications, 77\% were approved, for which the necessary assistance was provided. [26]

\section{CONCLUSION}


This confirms the thesis that in difficult times new opportunities for development appear, society is rallying, activates its full potential and begins to improve itself. Moreover, in the conditions of Uzbekistan, this positive dynamics testifies to the growth of social activity and responsibility of the citizens of our country for its current and future development.

In general, as follows from many examples of the development of the mechanism of social partnership in Uzbekistan, given in this article, one of the most positive tendencies in the consistent development of dialogue between state bodies and civil society institutions in the country is the expansion of the practice of delegating a part of traditionally state functions (mainly socially oriented functions or functions with the nature of public control) to individual institutions of civil society, while maintaining leadership functions for state bodies.

In this regard, a limited but consistent strengthening of the interaction of civil society with the state is gradually taking place. In this context, it is necessary to ensure further consolidation in the republic of the above-mentioned practice, which will contribute to the qualitative formation of a national model for the development of civil society and its institutions as the basis for creating a complete system of functioning of civil society in Uzbekistan.

\section{References}

1. Report of the President of the Republic of Uzbekistan Shavkat Mirziyoyev at the solemn meeting dedicated to the $25^{\text {th }}$ anniversary of the adoption of the Constitution of the Republic of Uzbekistan. //https://www.norma.uz/nashi obzori/konstituciya osnova nashey svobodnoy i blag opoluchnoy jizni dalneyshego razvitiya i procvetaniya strany

2. Law of the Republic of Uzbekistan "On Social Partnership" dated September 25, 2014 // Collected Legislation of the Republic of Uzbekistan. - 2014, No. 39, Art. 488; 2017, no. 37 , art. 978.

3. The law "On public-private partnership" shall be considered at the plenary session of the Senate. // http://xs.uz/uzkr/post/senat-yalpi-mazhlisida-davlat-khususijsheriklik-togrisidagi-qonun-korib-

chiqiladi?utm \%20source=uznet.press\&utm campaign=topic

4. Law of the Republic of Uzbekistan "On public-private partnership"// : https://lex.uz/ru/docs/4329272

5. Regulations on the State fund of support of business activity /https://nrm.uz/contentf?doc=612092 tadbirkorlik faoliyatini qo\%E2\%80\%98llabquv vatlash davlat jamg\%E2\%80\%98armasi to $\%$ E2\%80\%98g\%E2\%80\%98risida nizom (o \%E2\%80\%98zr vm 16012020 y 28-son qaroriga 2 ilova)\&products $=1$ vse zakonodatelstvo uzbekistana

6. Committee on Interethnic Relations and Friendship with Foreign Countries under the Cabinet of Ministers of the Republic of Uzbekistan //Инт. https://interkomitet.uz/mita-a-ida/millij-madanij-markazlar/?lang=0z

7. On the formation of a public fund for support and development, the development of free, independent media // https://lex.uz/docs/1159190

8. Chamber of Advocates of the Republic of Uzbekistan // https://paruz.uz/

9. El-Yurt Umid Foundation // I. https://eyuf.uz/ 
10. On measures to further improve the activities of the Writers' Union of Uzbekistan //. http://uza.uz/oz/documents/zbekiston-yezuvchilar-uyushmasifaoliyatini-yanada-takomilla-05-04-2018

11. Resolution of the Cabinet of Ministers of the Republic of Uzbekistan No. 124 dated February 13, 2019 "On measures to organize the activities of a non-governmental non-profit organization-National Movement" Yuksalish "and its territorial divisions" // National database of legislation, February 14, 2019, No. 09 / 19/124/2608.

12. Uzbekistan created the National Movent "Yuksalish"//:https://nuz.uz/politika/38533-v-uzbekistane-sozdanoobschenacionalnoe-dvizhenie-yuksalish.html

13. For example, the Public Council under the Khokimiyat of Tashkent city, district khokimiyats, under the Ministry for the Development of Information Technologies and Communications, the Ministry of Defense, the Ministry of Culture and Sports, the Ministry of Labor and Social Protection and other state institutions.

14. 14. NANNOUz was established in 2005 on the initiative of 150 public organizations of the country and currently unites more than 550 NGOs. The Association consolidates the organizational and intellectual resources of NGOs to implement the priority tasks of state and social construction, democratic reforms to form a free and open, strong civil society in the country.

15. 15. Resolution of the President of the Republic of Uzbekistan dated August 08, 2017 No. PP-3182 // Collected Legislation of the Republic of Uzbekistan, 2017, No. 32, art. 802; National Database of Legislation, 03.03.2018, No. 06/18/5329/0846; 06/08/2018, No. 06/18/5457/1324, 01/09/2019, No. 07/19/4102/2434.

16. My opinion "special web portal was created.//:http://www.uza.uz/oz/society/mening-fikrim-makhsus-veb-portali-yaratildi$\underline{20-04-2018}$

17. 17. Decree of the President of the Republic of Uzbekistan dated May 04, 2018 No.UP-5430 "On measures to radically increase the role of civil society institutions in the process of democratic renewal of the country" // National Legislation Database, 05.05.2018, No. 06/18 / 5430/1164.

18. 18. Decree of the President of the Republic of Uzbekistan dated August 8, 2018 No.UP-5505 "On approval of the Concept for improving the rule-making activity" // National database of legislation, 08/09/2018, No. 06/18/5505/1639; National database of legislation, 09.11.2019, No. 06/19/5870/4010.

19. 19. Resolution of the Cabinet of Ministers of the Republic of Uzbekistan dated October 20, 2018 "On measures to implement national goals and objectives in the field of sustainable development for the period up to 2030" // National database of legislation, 23.10.2018, No. 09/18 / 841/2081, 04.06.2019, No. 09/19/457/3235; 06/27/2020, No. $09 / 20 / 411 / 1000$.

20. 20. Decree of the President of the Republic of Uzbekistan dated November 14, 2018, No. PP-4017 "On measures to establish a badge" For contribution to the development of civil society "// National database of legislation, 15.11.2018, No. 07/18 / 4017/2188; 12/14/2019, No. 06/19/5894/4161.

21. 21. Decree of the President of the Republic of Uzbekistan dated October 04, 2019 No. PP-4473 "On additional measures to increase the efficiency of public control over the ongoing reforms in the socio-economic sphere, as well as the activity of citizens in the 
implementation of democratic transformations in the country" // National base data of legislation, 05.10.2019, No. 07/19/4473/3864.

22. Pekkanen, R. (2006), Japan's dual civil society: members without advocates, Stanford, California: Stanford University Press.

23. Краудсорсинг (crowdsourcing) - attracting a large number of volunteers to perform the work, transferring some functions and tasks to an indefinite circle of performers acting on a voluntary basis. Crowdsourcing is derived from the English words "crowd" and "sourcing".

24. Hope only for yourself: in Uzbekistan activists have created the movement "DYSHI, UZBEKISTAN"//. https://nuz.uz/sobytiya/1160307-v-uzbekistane-aktivistysozdali-dvizhenie-dyshi-uzbekistan.html

25. Telegram bot was launched in Uzbekistan helping the needy //https://daryo.uz/k/2020/07/20/ozbekistonda-muhtojlarga-yordam-korsatuvchitelegram-bot-ishga-tushirildi/ 